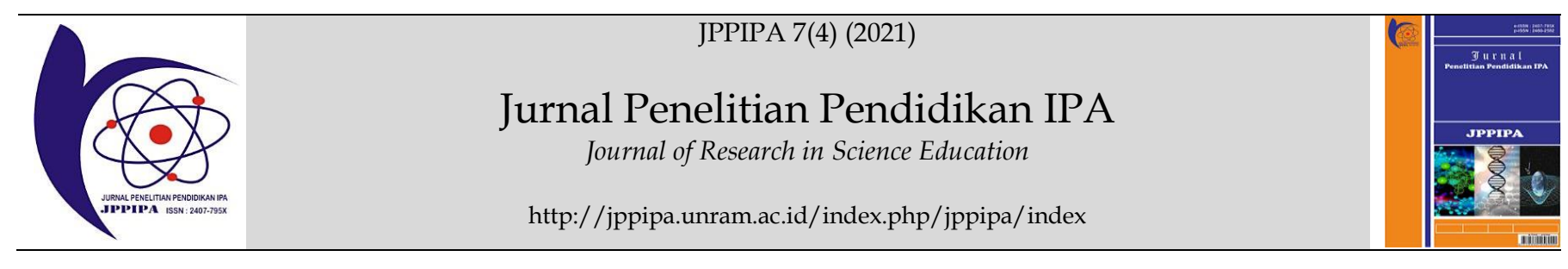

\title{
The Relationship between Multiple Intelligences and Biology Learning Outcomes of Student
}

\author{
Rika Andima1*, Ramadhan Sumarmin'1, Yuni Ahda1 ${ }^{1}$ Heffi Alberida1 , Abdul Razak1 \\ ${ }^{1}$ Biology Department, Faculty of Mathematics and Sciences, Universitas Negeri Padang - 25131, Indonesia
}

DOI: $\underline{10.29303 / \text { ippipa.v7i4.778 }}$

\section{Article Info}

Received : June $2^{\text {nd }}, 2021$

Revised : September 19th, 2021

Accepted : October 8th, 2021

\begin{abstract}
The achievement of learning objectives can be seen from the learning outcomes obtained by students after the learning process. Appropriate learning strategies by paying attention to multiple intelligences in students can affect learning outcomes. This research aims to analyze the relationship of intelligence learning outcomes with the student's biological learning outcomes. This research was conducted on 1st-grade students of natural sciences at Padang High School. The sampling technique is stratified using purposive sampling and proportional random sampling. The research instrument used multiple intelligence questionnaires and multiple-choice questions. The data in this study were analyzed using the Spearman rank correlation test. The results showed that each multiple intelligences had a significant relationship with student learning outcomes, except for three types of intelligence: visual-spatial, physical kinesthetic, and intrapersonal intelligence.
\end{abstract}

Keywords: Multiple Intelligences; learning outcomes; Biology

Citation: Andima, R., Sumarmin, R., Ahda, Y., Alberida, H., \& Razak, A. (2021). The Relationship between Multiple Intelligences and Biology Learning Outcomes of Student. Jurnal Penelitian Pendidikan IPA, 7(4), 625-631. doi:https://doi.org/10.29303/jppipa.v7i4.778

\section{Introduction}

One of the teacher's roles is to apply appropriate learning strategies to improve student learning outcomes. Learning outcomes are abilities possessed by students after receiving learning. Internal and external factors influence student learning outcomes. Intelligence is one of the internal factors that affect learning outcomes (Dwijuniar \& Anggoro, 2019). The intelligence in question is multiple intelligences: linguistic, logical-mathematical, spatial-visual, kinesthetic, musical, interpersonal, intrapersonal, naturalist, and existentialist (Adityas, 2016).

These various types of intelligence do not operate independently but can be used at the same time and tend to complement each other when someone solves a problem, as well as in the learning process. Everyone has multiple intelligences at different levels. Therefore, every teacher should be able to understand the intelligence and abilities of each student well because the circumstances of children in one class are different and have different degrees of intelligence. This is related to the teacher's role as a facilitator and motivator. According to Rahmawati (2019), teachers make plans to evaluate activities and interact directly during learning as a facilitator.

Multiple intelligences can be developed in biology learning activities (Kumalasari et al., 2017). Teachers have an essential role in helping develop the various intelligence possessed by students. The multiple intelligences possessed by students are often a measure of the success of students in learning. Some of the benefits for teachers if they already know multiple intelligences are that teachers become more focused on learning, help group students, and can approach according to the type of intelligence they possess.

Multiple intelligences in students can be seen in everyday behavior, one of which can be seen in the learning process at school. In the process of biological learning, students who have naturalistic intelligence are dominant. Students don't always get good biology learning outcomes because they also need other

\footnotetext{
*Email: rikaandima@gmail.com
} 
intelligence to get satisfactory learning outcomes. For example, the learning process must involve good interactions between students and teachers, students and school employees as well as between students in study groups or in the school environment, so that students who have linguistic and interpersonal intelligence levels can get better biology learning outcomes than students who have naturalist intelligence. In addition, biology subjects also contain terms, designations, symbols, and names of objects, natural phenomena, people, and places. Biology learning is also related to musical intelligence, for example, in understanding the difference between male and female animal sounds, while in visual-spatial intelligence, its application in biology learning is the use of interesting learning media so that students do not get bored of seeing it.

Researchers have conducted interviews with several biology teachers at high schools in Padang about multiple intelligences. Teachers already know about some intelligence but have not noticed and measured some of the intelligence possessed by students. Teachers are less precise in choosing learning strategies. Teachers are still fixated on one learning method without any variation. This causes students who are used to active in learning will get bored quickly, and lazy to pay attention to the teacher, so that the learning outcomes obtained are not as expected. This can be prevented if the teacher knows the condition of the students, one of which is by knowing the multiple levels of intelligence possessed by students.

Several previous authors have found that there is a link between students' multiple intelligences and the learning outcomes they get. Ege (2016) concludes that there is a relationship between multiple intelligences and learning outcomes. Furthermore, Saputra (2018) concludes that there is a relationship between interpersonal intelligence and student learning outcomes. Wajdi (2018) concludes that there is a relationship between naturalistic intelligence, interpersonal intelligence, and intrapersonal intelligence with student learning outcomes. The results of these studies are based on the overall parameters of multiple intelligences or just a few. Based on this description, to find out the relationship between multiple intelligences of each student and the biology learning outcomes obtained, a study was conducted on the relationship between multiple intelligences and the biology learning outcomes of students.

\section{Method}

This research is a descriptive study that has been conducted on students at the $1^{\text {st }}$ Grade of Natural
Sciences in Senior High Schools Padang. The population in this study were all students of the $1^{\text {st }}$ Grade of Natural Sciences in Senior High Schools Padang. The sampling technique is stratified using purposive sampling and proportional random sampling. The analytical technique used in this research is the Spearman Rank correlation analysis technique, and then hypothesis testing is carried out. Prior to the correlation analysis, the normality test was first performed. The research instrument used a questionnaire and multiple-choice questions.

Collecting data on the multiple intelligences of students in this study used an instrument in the form of a questionnaire consisting of 54 questions for nine types of intelligence, and the validity of the questionnaire was tested. The questionnaire uses a Likert scale with four alternative answers to the questions given, namely Always, Often, Rarely, and Never. Each alternative answer has a value of $4,3,2$, and 1 . The questionnaire is useful to determine the type of multiple intelligences that is most dominant in students. Student learning data in the form of questions containing scientific literacy with fungi, plantae, and animalia materials spread across 40 questions.

\section{Result and Discussion}

In this research, the correlation formula was used Sparman Rank to determine the relationship between multiple intelligences and learning outcomes. The correlation criteria between each multiple intelligences and the biology learning outcomes ranged from very weak to weak. The correlation coefficient value is between -1 to 1 , while the direction is expressed in positive and negative forms. The results of the calculation of the relationship between multiple intelligences and student learning outcomes can be seen in Table 1.

Table 1. Correlation of Multiple Intelligences and Learning Outcomes

\begin{tabular}{llll}
\hline Variable & & $\begin{array}{l}\text { Coefficient } \\
\text { Multiple Intelligences }\end{array}$ & $\begin{array}{c}\text { XLearning } \\
\text { Correlation }\end{array}$ \\
\cline { 1 - 2 } Types of Intelligence & $X$ & Outcomes & \\
Linguistic & 18,80 & 72,75 & 0,13 \\
Logical-mathematical & 20,58 & & 0,13 \\
Spatial-visual & 18,86 & 0,04 \\
Kinesthetic & 20,34 & 0,06 \\
Musical & 19,56 & 0,29 \\
Interpersonal & 18,84 & 0,14 \\
Intrapersonal & 18,26 & 0,09 \\
Naturalist & 21,35 & 0,24 \\
Existentialist & 19,06 & 0,11 \\
\hline
\end{tabular}

The determinant coefficient formula is used to see the contribution between two variables. The 
determinant coefficient of multiple intelligences with learning outcomes can be seen in Table 2 .

Table 2. Determinant Coefficient of Multiple Intelligences with Learning Outcomes

\begin{tabular}{|c|c|c|c|}
\hline \multicolumn{3}{|l|}{ Variable } & \multirow{3}{*}{$\begin{array}{l}\text { Coefficient } \\
(\%)\end{array}$} \\
\hline Multiple Intelligences & & \multirow{2}{*}{$\begin{array}{l}\text { X Learning } \\
\text { Outcomes }\end{array}$} & \\
\hline Types of Intelligence & $\bar{X}$ & & \\
\hline Linguistic & 18,80 & 72,75 & 1,88 \\
\hline Logical-mathematical & 20,58 & & 1,85 \\
\hline Spatial-visual & 18,86 & & 0,19 \\
\hline Kinesthetic & 20,34 & & 0,48 \\
\hline Musical & 19,56 & & 8,82 \\
\hline Interpersonal & 18,84 & & 2,04 \\
\hline Intrapersonal & 18,26 & & 0,90 \\
\hline Naturalist & 21,35 & & 5,81 \\
\hline Existentialist & 19,06 & & 1,32 \\
\hline
\end{tabular}

The t-test was used to test the significance of the relationship between the independent variables and the dependent variable. According to Riduwan in Safitri (2017), the test criterion is if $F_{\text {count }} \geq F_{\text {table }}$ at a significant level of $5 \%(0.05)$, then there is a significant relationship between each multiple intelligences and student learning outcomes. Furthermore, to determine whether there is a significant relationship, a t-test is used with a $t_{\text {table }}$ value of 1.96. The t-test of multiple intelligences overall and biology learning outcomes can be seen in Table 3.

Table 3. Recapitulation of t-test results

\begin{tabular}{|c|c|c|c|}
\hline \multicolumn{3}{|l|}{ Variable } & \multirow[t]{3}{*}{$t_{\text {count }}$} \\
\hline Multiple Intelligences & & \multirow{2}{*}{$\begin{array}{l}\text { X Learning } \\
\text { Outcomes }\end{array}$} & \\
\hline Types of Intelligence & $\bar{x}$ & & \\
\hline Linguistic & 18,80 & 72,75 & 2,38 \\
\hline Logical-mathematical & 20,58 & & 2,36 \\
\hline Spatial-visual & 18,86 & & 0,75 \\
\hline Kinesthetic & 20,34 & & 1,19 \\
\hline Musical & 19,56 & & 5,36 \\
\hline Interpersonal & 18,84 & & 2,49 \\
\hline Intrapersonal & 18,26 & & 1,64 \\
\hline Naturalist & 21,35 & & 4,27 \\
\hline Existentialist & 19,06 & & 1,99 \\
\hline
\end{tabular}

\section{The Relationship of Linguistic Intelligence and Learning Outcomes}

Based on the results of data analysis, it is known that linguistic intelligence has a significant relationship with student learning outcomes. It can be seen from Table 3, the value of $t_{\text {count }}(2.38)$ is greater than $t_{\text {table }}$ (1.96). The correlation test results between linguistic intelligence and student learning outcomes are classified as very weak, with a coefficient of 0.13 . Although the correlation coefficient is very weak, it has a positive relationship, meaning that if linguistic intelligence increases, students' learning outcomes will also increase. The coefficient of determination is $1.88 \%$.
This means that students' learning outcomes are influenced by their linguistic intelligence as much as $1.88 \%$.

Based on the observations of researchers, teachers often use the group discussion method. The teacher also assigns students to make a summary of the material discussed. This kind of learning process can improve students' linguistic intelligence. During the learning process, there are some students who do not do the assignments given by the teacher. Students only copy the assignments of other students. This causes the correlation of students' linguistic intelligence with learning outcomes to be classified as very weak.

Linguistic intelligence and student learning outcomes in this study were declared significant so that there was a significant relationship between linguistic intelligence and student learning outcomes. According to Riswandi (2017), improving learning outcomes can be done by increasing students' linguistic intelligence. This is in line with the opinion of Hasibuan (2019) and Aini (2017) that there is a relationship between linguistic intelligence and learning outcomes, the higher the linguistic intelligence, the higher the learning outcomes tend to be.

\section{The Relationship of Logical-Mathematical Intelligence and Learning Outcomes}

Based on the results of data analysis, it is known that logical-mathematical intelligence has a significant relationship with student learning outcomes. It can be seen from Table 3 , the value of $t_{\text {count }}$ (2.36) is greater than $t_{\text {table }}(1.96)$. The correlation test results between logical-mathematical intelligence and student learning outcomes are classified as very weak, with a coefficient of 0.13 . Although the correlation coefficient is very weak, it has a positive relationship, meaning that if logical-mathematical intelligence increases, student learning outcomes will also increase. The coefficient of determination is $1.85 \%$. This means that students' learning outcomes are influenced by their logical-mathematical intelligence as much as $1.85 \%$.

Based on the observations of researchers, students prefer to do experiments in the laboratory. However, students rarely analyze and study the cause and effect of something, so the correlation of logicalmathematical intelligence with learning outcomes is very weak. The learning process is also focused on memorizing a series of words and noting the material presented by the teacher through learning media.

Logical-mathematical intelligence and student learning outcomes are stated to be significant, so there is a significant relationship between logicalmathematical intelligence and student learning outcomes. The results of this study are supported by 
the opinions of Milsan (2018) and Muchlisa (2018) that there is a relationship between logical-mathematical intelligence and learning outcomes; the higher the logical-mathematical intelligence, the learning outcomes tend to be higher.

\section{The Relationship of Visual-Spatial Intelligence and Learning Outcomes}

Based on the results of data analysis, it is known that visual-spatial intelligence has an insignificant relationship with student learning outcomes. This can be seen from the value of $t_{\text {count }}$ (0.75) which is smaller than table (1.96). The correlation test results between visual-spatial intelligence and student learning outcomes are classified as very weak, with a coefficient of 0.04 . Although the correlation coefficient is very weak, it has a positive relationship, meaning that if visual-spatial intelligence increases, student learning outcomes will also increase. The coefficient of determination is $0.19 \%$. This means that students' learning outcomes are influenced by their visual-spatial intelligence as much as $0.19 \%$.

Visual-spatial intelligence has an insignificant relationship with students' biology learning outcomes. Based on the researchers' observations, the learning media is not optimally used by teachers in the learning process. This causes students who have dominant visual-spatial intelligence to be less interested in learning so that this intelligence has an insignificant relationship with learning outcomes. Teachers can apply learning media in the form of torsos, graphs, and charts so that students who have dominant visualspatial intelligence are more interested in learning by seeing and observing pictures. This is in line with the opinion of Sener (2018), and Agustina (2017) that students with visual-spatial intelligence can perceive images, absorb learning when presented with the help of visual objects, and tend to have better learning patterns with visual objects see rather than listen.

Visual-spatial intelligence has a very weak correlation with students' cognitive learning outcomes. The results of this study are supported by the opinion of Mardiah (2017) and Setyawan (2018) that there is a relationship between visual-spatial intelligence and learning outcomes; the higher the visual-spatial intelligence, the higher the learning outcomes tend to be. Thus, improving learning outcomes can be done by increasing visual-spatial intelligence.

\section{The Relationship of Physical Kinesthetic Intelligence and Learning Outcomes}

Based on the results of data analysis, it is known that physical kinesthetic intelligence has an insignificant relationship with student learning outcomes. It can be seen from Table 3 , the value of $t_{\text {count }}$
(1.19) is smaller than $t_{\text {table }}(1.96)$. The correlation test results between physical kinesthetic intelligence and student learning outcomes are classified as very weak, with a coefficient of 0.06 . Although the correlation coefficient is very weak, it has a positive relationship, meaning that if physical kinesthetic intelligence increases, students' learning outcomes will also increase. The coefficient of determination is $0.48 \%$. This means that their physical kinesthetic intelligence influences students' learning outcomes as much as $0.48 \%$.

Physical kinesthetic intelligence and learning outcomes are not significant, but there is a weak relationship between physical kinesthetic intelligence and student learning outcomes. The results of this study are supported by the opinion of Ahvan (2016) that there is a relationship between physical kinesthetic intelligence and learning outcomes, the higher the physical kinesthetic intelligence, the higher the learning outcomes tend to be. Thus, improving learning outcomes can be done by increasing physical kinesthetic intelligence.

\section{The Relationship of Musical Intelligence with Learning Outcomes}

Based on the results of data analysis, it is known that musical intelligence has a significant relationship with student learning outcomes. It can be seen from Table 3, the value of $t_{\text {count }}$ (5.36) is greater than $t_{\text {table }}$ (1.96). The correlation test results between musical intelligence and student learning outcomes are classified as weak, with a coefficient of 0.29 . Although the correlation coefficient is weak, it has a positive relationship, meaning that if musical intelligence increases, student learning outcomes will also increase. The coefficient of determination is $8.82 \%$. This means that the learning outcomes of students' biology are influenced by their musical intelligence as much as $8.82 \%$.

Based on the observations of researchers, students like to listen and remember the rhythm of the music. Teachers can apply this in learning by using music by replacing the lyrics of songs that students like with lesson points that are difficult for students to remember and understand. This is in line with Leonard's opinion (2018) that learning that can improve students' musical intelligence is learning that is interspersed with things that contain elements of music in it.

Musical intelligence and student learning outcomes in this study were stated to be significant so that there was a significant relationship between musical intelligence and student learning outcomes. The results of this study are supported by the opinion of Jamil (2019) and Ahvan (2016) that there is a 
relationship between musical intelligence and learning outcomes; the higher the musical intelligence, the higher the learning outcomes tend to be. Thus, improving learning outcomes can be done by increasing musical intelligence.

\section{The Relationship of Interpersonal Intelligence and Learning Outcomes}

Based on the results of data analysis, it is known that interpersonal intelligence has a meaningful relationship with student learning outcomes. This can be seen from Table 3 that the value of $t_{\text {count }}(2.49)$ is greater than $t_{\text {table }}$ (1.96). The correlation test results between interpersonal intelligence and student learning outcomes are classified as very weak, with a coefficient of 0.143 . Although the correlation coefficient is very weak, it has a positive relationship, meaning that if interpersonal intelligence increases, students' learning outcomes will also increase. The coefficient of determination is $2.04 \%$. This means that students' learning outcomes are influenced by their interpersonal intelligence as much as $2.04 \%$.

Based on the observations of researchers, students enjoy interacting with peers and enjoy working in groups. Teachers in learning can apply this by using the group discussion method in the learning process. In groups, students interact with other students. Appropriate learning, supporting facilities, and guidance from teachers can develop the interpersonal intelligence possessed by students. This is in line with Rofiah's (2016) opinion, which states that students with interpersonal intelligence will easily communicate and relate to other people. Students will prefer group activities.

Interpersonal intelligence and student learning outcomes are declared significant, so there is a significant relationship between interpersonal intelligence and student learning outcomes. This is supported by Saputra's (2018) opinion, which says that there is a positive and significant relationship between interpersonal intelligence and learning outcomes. So, the higher the interpersonal intelligence of students, the higher the learning outcomes tend to be.

\section{Relationship of Intrapersonal Intelligence with Learning Outcomes}

Based on the results of data analysis, it is known that intrapersonal intelligence has an insignificant relationship with student learning outcomes. This can be seen from the value of $t_{\text {count }}$ (1.64) which is smaller than $t_{\text {table }}(1.96)$. The correlation test results between intrapersonal intelligence and student learning outcomes are classified as very weak, with a coefficient of 0.095. Although the correlation coefficient is very weak, it has a positive relationship, meaning that if intrapersonal intelligence increases, student learning outcomes will also increase. The coefficient of determination is $0.90 \%$. This means that student learning outcomes are influenced by their intrapersonal intelligence as much as $0.90 \%$. There is a relationship between intrapersonal intelligence and learning outcomes (Huda, 2021; Firmansyah, 2016). The higher the intrapersonal intelligence, the higher the learning outcome. Thus, improving learning outcomes can be done by increasing intrapersonal intelligence.

Based on the observations of researchers, teachers often give independent assignments to students during the learning process. Students are often given rewards to be motivated in learning. Learning activities like this can develop interpersonal intelligence in students. The correlation between intrapersonal intelligence and student learning outcomes is very low. This is because some schools have not performed optimally in the application of awards for students who are able to complete tasks well in learning and learning, so they have not been able to motivate and improve themselves.

\section{The Relationship of Naturalist Intelligence with Learning Outcomes}

Based on the results of data analysis, it is known that naturalist intelligence has a significant relationship with student learning outcomes. This can be seen from Table 3 that the value of $t_{\text {count }}(4.27)$ is greater than $t_{\text {table }}(1.96)$. The correlation test results between naturalist intelligence and the learning outcomes are classified as weak, with a coefficient of 0.24 . Although the correlation coefficient is weak, it has a positive relationship, meaning that if naturalist intelligence increases, students' learning outcomes will also increase. The coefficient of determination is $5.81 \%$. This means that their naturalist intelligence of $5.81 \%$ influences students' Biology learning outcomes.

Based on the observations of researchers, students enjoy learning about nature. Teachers in learning can apply this by carrying out the learning process outside the classroom to increase the naturalist intelligence of students. The school has a laboratory and schoolyard that can be used as an alternative place for learning to take place other than the classroom. Ege (2016) states that students with naturalistic intelligence have the ability to categorize and create hierarchies of the state of organisms such as plants, animals, and nature.

Naturalist intelligence and student learning outcomes in this study were declared significant so that there was a significant relationship between naturalist intelligence and student learning outcomes. There is a relationship between naturalist intelligence and learning outcomes (Wajdi, 2018; Nurlia, 2020). The 
higher the naturalist intelligence, the higher the learning outcomes tend to be. Thus, improving learning outcomes can be done by increasing naturalist intelligence.

\section{The Relationship of Existential Intelligence and Learning Outcomes}

Based on the results of data analysis, it is known that existential intelligence has a significant relationship with students' learning outcomes. It can be seen from Table 3 that the value of $t_{\text {count }}(1.99)$ is greater than $t_{\text {table }}$ (1.96). The correlation test results between existential intelligence and the learning outcomes are classified as very weak, with a coefficient of 0.11 . Although the correlation coefficient is very weak, it has a positive relationship, meaning that if existential intelligence increases, student learning outcomes will also increase. The coefficient of determination is $1.32 \%$. This means that students' learning outcomes are influenced by their existential intelligence as much as $1.32 \%$.

Based on the observations of researchers, students like to ask questions that other students rarely ask. Students with existential intelligence are able to think about things that other people don't think of, such as the origin of plants and what happens after plants die.

Existential intelligence and student learning outcomes are declared significant, so there is a significant relationship between existential intelligence and student learning outcomes. The results of this study are supported by Pasiak's (2018) opinion that there is a relationship between existential intelligence and learning outcomes. The higher existential intelligence, the higher learning outcomes tend to be.

\section{Conclusion}

Based on the results of the study, it can be concluded that each multiple intelligence has a significant relationship with the learning outcomes of students, except for three types of intelligence, namely spatial-visual intelligence, physical-kinesthetic intelligence, and intrapersonal intelligence.

\section{References}

Adityas, M. T. (2016). Activating Students' Multiple Intelligences in Speaking Activities. Ahmad Dahlan Journal of English Studies, 3(1), 70. https://doi.org/10.26555/adjes.v3i1.3642

Agustina, L. (2017). Kecerdasan Visual-Spasial pada Anak Berkesulitan Belajar Matematika. Prosiding Seminar Nasional Matematika dan Pendidikan Matematika (Sesiomadika), ISBN: 978-602-60550-19. [Indonesian]
Ahvan, Y.R., \& Pour, H.Z. (2016). The Correlation of Multiple Intelligences for the Achievement of Secondary Students. Educational Research and Reviews, 14(4): 141-145. doi: https://10.5897/ERR2015.2532

Aini, D.N., Sitompul, N.C., \& Juniarso, T. (2017). Hubungan Antara Kecerdasan Linguistik dengan Hasil Belajar Ilmu Pengetahuan Alam Siswa SD Laboratorium UNESA. Jurnal Inventa, 1(1), 10-16. doi: https://doi.org/10.36456/inventa.1.1.a2003 [Indonesian]

Dwijuniar, Y., \& Anggoro, R. (2019). The Relationship Between Learning Interest and Learning Independence Toward Mathematics Learning Outcomes. AdMathEduSt: Jurnal Ilmiah Mahasiswa Pendidikan Matematika, 6(12), 654-661. doi: http://dx.doi.org/10.12928/admathedust.v6i12. 19486.

Ege, B. (2016). Hubungan antara Multiple Intelligences dengan Hasil Belajar Kognitif Siswa pada Mata Pelajaran Ilmu Pengetahuan Alam. Prosiding Semnas Pendidikan IPA Pascasarjana, 1(1), 863-872. [Indonesian]

Firmansyah., \& Nurzaelani, M.M. (2016). Hubungan antara Kecerdasan Intrapersonal dan Rasa Percaya Diri dengan Hasil Belajar Mata Pelajaran Bahasa Inggris. Jurnal Teknologi Pendidikan, 5(2): 19-39. doi: http://dx.doi.org/10.32832/tek.pend.v5i2.496 [Indonesian]

Hasibuan, M.F. (2019). Hubungan Kecerdasan Linguistik dengan Hasil Belajar Matematika Siswa Kelas XI SMA Taman Siswa Lubuk Pakam. Journal of Computer Networks, Architecture and High Performance Computing, 1(1), 41-48. doi: https://10.47709/cnapc.v1i1.444 [Indonesian]

Huda, M. \& Arief, A. (2013). Pengaruh Multiple Intelligences Menggunakan Model Pembelajaran Kooperatif Tipe Jigsaw Terhadap Hasil Belajar Siswa Pada Pokok Bahasan Listrik Dinamis Kelas $X$ di SMAN 1 Porong. Jurnal Inovasi Pendidikan Fisika, 2(3): 34-37. Retrieved from https://jurnalmahasiswa.unesa.ac.id/index.php index/index [Indonesian]

Jamil, U. (2019). Hubungan Kecerdasan Musikal dengan Kemampuan Mata Pelajaran Matematika Siswa Kelas IV Sekolah Dasar. JPGSD 7(7): 3764$3773 . \quad$ Retrieved from https://jurnalmahasiswa.unesa.ac.id/index.php Lindex/index [Indonesian]

Kumalasari, L., Yusuf Hilmi, A., \& Priyandoko, D. (2017). The Application of Multiple Intelligence Approach to The Learning of Human Circulatory System. Journal of Physics: Conference Series, 
909(1).

https://doi.org/10.1088/1742-

6596/909/1/012066

Mardiah, H., Monawati, \& Fauzi. (2017). Hubungan Kecerdasan Spasial Visuak terhadap Hasil Belajar Matematika Materi Bangun Ruang Siswa Kelas 5 SD Negeri 5 Banda Aceh. Jurnal Ilmiah Pendidikan Guru Sekolah Dasar, 2(1): 48-60. Retrieved from http://www.jim.unsyiah.ac.id/pgsd/article/vie w/4393 [Indonesian]

Milsan, A.L., \& Wewe, M. (2018). Hubungan Antara Kecerdasan Logis Matematis dengan Hasil Belajar Matematika. Journal of Education Technology, 2(2), 65-69. Retrieved from https://ejournal.undiksha.ac.id/index.php/JET Larticle/viewFile/16183/11496 [Indonesian]

Muchlisa, S. (2018). Hubungan Antara Kecerdasan Logis Matematis dengan Hasil Belajar Matematika Siswa di Kelas IV SD Negeri 26 Banda Aceh. Jurnal ilmiah pendidikan guru sekolah dasar, 3(1), 66-71. Retrieved from http://www.jim.unsyiah.ac.id/pgsd/article/vie $\mathrm{w} / 8640$ [Indonesian]

Nurlia \& Anggro, S. (2020). Hubungan Kecerdasan Naturalistik dan Minat Belajar dengan Hasil Belajar Biologi SMA di Kota Luwuk". Jurnal Pendidikan Glasser, 4(2): 97-106. doi: https://doi.org/10.32529/glasser.v4i2.687

Pasiak, T., Dachrud, M., \& Darise, G.N. (2018). Hubungan antara Kecerdasan Interpersonal dan Kecerdasan Eksistensial Spiritual dengan Indeks Prestasi Kumulatif (IPK) Mahasiswa IAIN Manado. Journal of Islamic Education Policy, 3(2), 116-124.

doi:

http://dx.doi.org/10.30984/j.v3i2.865

[Indonesian]

Rahmawati, M. \& Suryadi, E. (2019). Guru Sebagai Fasilitator dan Efektivitas Belajar Siswa. Jurnal Pendidikan Manajemen Perkantoran. 4(1), 49- 54. doi: 10.17509/jpm.v4i1.14954 [Indonesian]

Rofiah, N.H. (2016). Menerapkan Multiple Intelligences dalam Pembelajaran di Sekolah Dasar. Jurnal Dinamika Pendidikan Dasar, 8(1): 68-79. doi: 10.30595/dinamika.v8i1.937 [Indonesian]

Safitri, A., Hasmunir., \& Kamaruddin, T. (2017). Hubungan Minat Baca dan Motivasi Belajar dengan Hasil Belajar IPS Terpadu Siswa Kelas VII MTsN Kutabaro. Jurnal Ilmiah Mahasiswa Pendidikan Geografi FKIP Unsyiah, 2(1): 49-61. Retrieved

from: http://www.jim.unsyiah.ac.id/geografi/article/ view $/ 5075$ [Indonesian]

Saputra, A., Sujana, \& Manuaba, S. (2018). Korelasi antara Kecerdasan Intepersonal dengan Hasil Belajar IPS Siswa Kelas V". Jurnal Mimbar Ilmu,
23(1):

43-52.

doi:

http://dx.doi.org/10.23887/mi.v23i1.16406

[Indonesian]

Sener, S. \& Cokcaliskan, A. (2018). An Investigation between Multiple Intelligences and Learning Style. Journal of Education and Training Studies, 6(2): $\quad 125-132 . \quad 018 . \quad$ doi: https://10.11114/jets.v6i2.2643

Setyawan, R., \& Herawati. (2018). Hubungan antara Kecerdasan Spasial Visual dengan Hasil Belajar Ilmu Pengetahuan Alam (IPA) Kelas VIII di SMP Negeri 1 Kemang Kabupaten Bogor. Jurnal Educate, 3(2): 206-216. doi: http://dx.doi.org/10.32832/educate.v3i2.1212 [Indonesian]

Wajdi, M. (2018). Hubungan Kecerdasan Naturalistik, Kecerdasan Interpersonal, dan Kecerdasan Intrapersonal dengan Hasil Belajar Siswa Kelas XI IPA SMA Negeri di Kota Makassar. UNM Journal of Biological Education, 2(1): 13-19. Retrieved from: https://ojs.unm.ac.id/UJBE/article/view/6507 [Indonesian] 